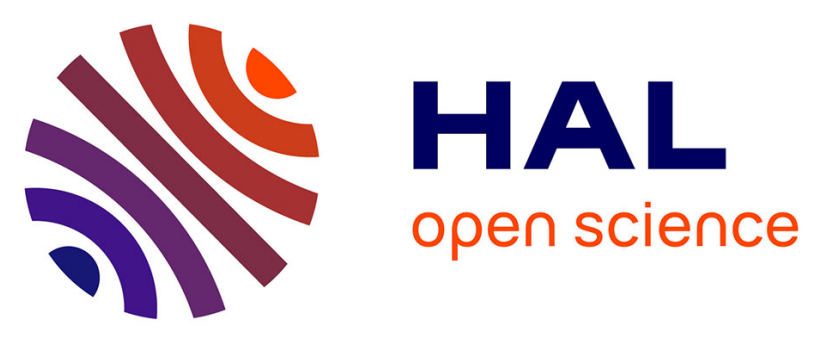

\title{
Production of formate from CO 2 gas under ambient conditions: towards flow-through enzyme reactors
}

\author{
Mohamed Baccour, Alexandra Lamotte, Kento Sakai, Eric Dubreucq, Ahmad
} Mehdi, Kenji Kano, Anne Galarneau, Jullien Drone, Nicolas Brun

\section{- To cite this version:}

Mohamed Baccour, Alexandra Lamotte, Kento Sakai, Eric Dubreucq, Ahmad Mehdi, et al.. Production of formate from CO 2 gas under ambient conditions: towards flow-through enzyme reactors. Green Chemistry, 2020, 22 (12), pp.3727-3733. 10.1039/D0GC00952K . hal-02884322

\section{HAL Id: hal-02884322 \\ https://hal.science/hal-02884322}

Submitted on 25 Nov 2020

HAL is a multi-disciplinary open access archive for the deposit and dissemination of scientific research documents, whether they are published or not. The documents may come from teaching and research institutions in France or abroad, or from public or private research centers.
L'archive ouverte pluridisciplinaire HAL, est destinée au dépôt et à la diffusion de documents scientifiques de niveau recherche, publiés ou non, émanant des établissements d'enseignement et de recherche français ou étrangers, des laboratoires publics ou privés. 


\title{
Production of formate from $\mathrm{CO}_{2}$ gas under ambient conditions: towards flow-through enzymes reactors*
}

\author{
Mohamed Baccour," Alexandra Lamotte, ${ }^{, 0,0}$ Kento Sakai, ${ }^{c}$ Eric Dubreucq, ${ }^{b}$ Ahmad Mehdi,, Kenji \\ Kano, ${ }^{\mathrm{C}}$ Anne Galarneau, "Jullien Drone ${ }^{*, \mathrm{a}}$ and Nicolas Brun*,sg
}

\begin{abstract}
A flow-through bi-enzymatic reactor was developed to produce formate from carbon dioxide gas $\left(\mathrm{CO}_{2}\right)$. The reaction operates under ambient conditions without hydrogen gas $\left(\mathrm{H}_{2}\right)$ and involves a high performance formate dehydrogenase from Methylobacterium extorquens AM1 (MeFoDH1). The tandem reaction features in situ regeneration of the nicotinamide adenine dinucleotide (1,4-NADH) cofactor performed by a highly active mutant of the phosphite dehydrogenase from Pseudomonas stutzeri, without any side reaction. One of the highest turnover number reported to date into the literature was reached (6 700) giving a high space-time yield of $0.6 \mathrm{mmol}_{\text {formate }} \mathrm{min}^{-1} \mathrm{~L}^{-1}$ reactor
\end{abstract}

Humankind is facing a carbon conundrum requiring a shift in energy economics paradigm. As mentioned in the last IPCC report, ${ }^{1}$ a drastic reduction of anthropogenic $\mathrm{CO}_{2}$ emissions is mandatory to follow pathways that limit global warming to 1.5 ${ }^{\circ} \mathrm{C}$ in 2100 . To achieve this objective, global $\mathrm{CO}_{2}$ emissions must reach net zero in the foreseeable future (2040 to 2055). In this context, low energy and low cost processes of carbon capture and its reuse appear as key challenges. $\mathrm{CO}_{2}$ should not be seen anymore as a waste but as an alternative carbon feedstock to produce platform chemicals and energy carriers. There is a need of innovation to develop such efficient technologies. Hydrogenation processes, producing formate/formic acid, methanol, dimethyl ether or hydrocarbons from $\mathrm{CO}_{2}$ and $\mathrm{H}_{2}$, have been largely studied and demonstrated at the pilot plant scale, but are high energy-consuming processes. ${ }^{2-4}$ Formic acid (FA) has been seen as a promising and safe hydrogen energy carrier $^{5}$ and its worldwide demand is expected to grow significantly in the context of renewable energy (see for example the HYFORM-PEMFC technology ${ }^{6}$ ). The global production of FA was 1015 kilotonnes (kt) in 2016 and it will reach $1217 \mathrm{kt}$ in $2022 .^{7}$ Usually, catalytic hydrogenative

\footnotetext{
a institut Charles Gerhardt Montpellier (ICGM), Univ Montpellier, CNRS, ENSCM, Montpellier (France)

a. Division of Applied Lfe Sciences, Graduate School of Agriculture, Kyoto University, Sakyo, Kyoto (Japan)

' ingénierie des Agropolymères et Technologies Emergentes, UMR LATE, Univ. Montpellier-Montpellier SupAgro-INRA-CIRAD, Mantpellier (France)

-Emails: nicolas.brun Eensom.fr iulliendrone@ensem.fir

Electronic Supplementary Information (ESI) available: [Experimental procedures and additional analytical datal. See DOl: 10.1039/×0x000000x
}

conversion involves high pressures and temperatures ( $>20$ bar and $140^{\circ} \mathrm{C}$ ) and requires the compression/concentration of $\mathrm{CO}_{2}$ and $\mathrm{H}_{2}$. As far as storage and safety are concerned, the use of high-pressure hydrogen gas might be a major drawback. $\mathrm{CO}_{2}$ is thermodynamically stable and its difficult chemical activation has incited the scientific community to seek sustainable catalytic processes running under milder conditions.

Amongst emerging strategies to produce valuable chemicals from $\mathrm{CO}_{2}$, electrochemical, ${ }^{8-12}$ photoelectrochemical ${ }^{13}$ and photochemical ${ }^{14-16}$ reduction routes have been seen as promising as they could offer chemical storage medium for intermittent electrical energy supplies. Particularly, several techno-economic analyzes indicate that the electrochemical $\mathrm{CO}_{2}$ reduction reaction $\left(\mathrm{CO}_{2} \mathrm{RR}\right)$ to produce formate/FA could soon be commercialized successfully. ${ }^{17-19}$ Recently, a few studies have reported encouraging results for the selective $\mathrm{CO}_{2} \mathrm{RR}$ to formate/FA in continuous modes, using flow cell reactors.9-12 These processes present, however, some constraints. Proietto et al. ${ }^{9}$ had to increase the $\mathrm{CO}_{2}$ pressure from 1 to 30 bars to increase the faradaic efficiency (FE, that is, the selectivity) from 15 to $70 \%$. Lee et al. ${ }^{10}$ and Xia et al. ${ }^{11}$ reported FE superior to $90 \%$ under ambient conditions, at moderate operational voltages (below $3 \mathrm{~V}$ ) and with high productivities (i.e. current densities up to $200 \mathrm{~mA} \mathrm{~cm}-2$ ). Nevertheless, due to competition with the hydrogen evolution reaction at the cathode,,$^{10}$ and to ion conductivity limitations at the membranes and in the electrolyte ${ }^{11}$, the highest energy efficiency was still inferior to $65 \%,{ }^{10}$ causing substantial energy losses. Moreover, $\mathrm{CO}_{2} \mathrm{RR}$ flow cells usually require the use of noble metal catalysts (e.g. platinum ${ }^{10,11}$ or iridium ${ }^{9,11}$ ) for the oxygen evolution reaction occurring at the anode, affecting their economic and environmental viability.

Another promising alternative lies in biocatalytic processes, as they run on relatively mild conditions, are ecologically-friendly ${ }^{20}$ and highly selective, and do not rely on electricity or sunlight to operate. Furthermore, the structurally well-defined and atomically well-dispersed active sites of metalloenzymes (or any other enzymes) make them a growing source of inspiration for the design of atom-economic catalysts. ${ }^{21}$ Several biocatalysts including enzymes and bacteria have been studied for the conversion of $\mathrm{CO}_{2}{ }^{22-24}$ Amongst them, formate dehydrogenases 
(FoDHs) have been widely reported, ${ }^{25}$ especially the commercially available FoDH from Candida boidinii ( $C b F O D H) .{ }^{26-}$ 31 The use of FoDHs presents, however, several major limitations amongst which, the low concentration of gaseous $\mathrm{CO}_{2}$ in aqueous solutions, due to equilibria with carbonic acid, carbonate and bicarbonate, the need for an expensive loosely bound cofactor, the low $\mathrm{CO}_{2}$-reducing activity and/or extreme oxygen sensitivity of most FoDHs. ${ }^{25}$ On the one hand, most oxygen-stable FoDHs, including $\mathrm{CbFoDH}$, exhibit low $\mathrm{CO}_{2}$ reducing activities. ${ }^{26}$ On the other hand, a few oxygen-stable FoDHs have demonstrated superior $\mathrm{CO}_{2}$-reducing properties, including FoDHs from Thiobacillus sp. KNK65MA (TsFoDH), ${ }^{32.34}$ Rhodobacter capsulatus, ${ }^{35}$ Clostridium carboxidivorans strain P7T, ${ }^{36}$ Desulfovibrio vulgaris Hildenborough (DvH-FoDH), ${ }^{37,38}$ and Methylobacterium extorquens AM1 (MeFoDH1). ${ }^{39-43}$

The latter is a soluble heterodimer with a tungstencontaining active site and five iron-sulfur clusters. ${ }^{39} \mathrm{MeFoDH} 1$ is stable under aerobic conditions, making it suitable for industrial applications, while most of the previously characterized metal-containing FoDHs were reported to be extremely oxygen-sensitive. ${ }^{25}$ MeFoDH1 is a NAD-dependent enzyme, requiring the cofactor nicotinamide adenine dinucleotide (NAD) in its active reduced form, 1,4-NADH. As NAD is relatively unstable and expensive, it has to be regenerated in situ ${ }^{44}$ (i.e. the oxidized form NAD has to be reduced to 1,4-NADH). In the last years, various strategies have been developed either to use artificial redox mediators or to selectively reduce $\mathrm{NAD}^{*}$ to $1,4-\mathrm{NADH}$. Besides catalytic, ${ }^{45}$ electrocatalytic ${ }^{46,47}$ and photocatalytic ${ }^{31,48-50}$ pathways largely employed for the in situ regeneration of 1,4-NADH, the enzymatic pathway using phosphite dehydrogenase (PtDH) has been seen as one of the most efficient. ${ }^{26,51-53}$ The latter is highly selective and clean, as it does not involve any additional reactants and leads to no by-products, except for the phosphite-phosphate couple already present in the buffered reaction medium. In our previous study, a PtDH mutant from Pseudomonas stutzeri (plasmid pET15b-PTDH12x; see section S1, Figure S1 in Supporting Information for more details) $)^{54}$ was associated with commercial dehydrogenases, in a cascade reaction including $\mathrm{CbFoDH}$, for the reduction of carbon dioxide into methanol. ${ }^{26}$ The low $\mathrm{CO}_{2}$-reducing activity of the commercial $\mathrm{CbFoDH}$ was seen, however, as a major obstacle to envision cost effective and productive enzyme-based catalytic processes. More recently, this multi-enzyme cascade reaction was significantly improved by Lee et al. ${ }^{53}$ by using recombinant dehydrogenases.

In the present study, stable MeFoDH1 has been used as a rational alternative, based on its superior activity of $\mathrm{CO}_{2}$ reduction compared to $\mathrm{CbFODH}$ and $T s F \mathrm{ODH}$ (see section $\mathrm{S} 2$, Figures S2-4). First, pure MeFoDH1 (168 kDa) and PtDH mutant ( $36 \mathrm{kDa}$ ) were combined with an excess of NAD+ in a tandem reaction in batch for the selective production of formate from $\mathrm{CO}_{2}$ gas (Figure 1a; section S3, Figures S5-7). Key parameters were adjusted to enhance formate productivity (section $\$ 4$ in Supporting Information). One of them is the solubility of $\mathrm{CO}_{2}$ in water. ${ }^{23}$ When sodium bicarbonate $\left(\mathrm{NaHCO}_{3}, 0.1 \mathrm{M}\right)$ was used as the sole source of $\mathrm{CO}_{2}$ in sodium phosphite buffer $(0.5 \mathrm{M}, \mathrm{pH}$
6.4), the production of formate was limited and could $d_{n}$ be

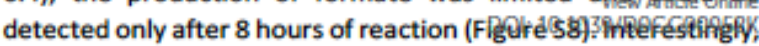
when $\mathrm{CO}_{2}$ bubbling was used together with $\mathrm{NaHCO}_{3}$, formate concentration drastically increased (Figure 58 ), while the $\mathrm{pH}$ was not significantly affected (from 6.4 to 6.3). In a recent publication, K. Fuji et al. reported that $\mathrm{CO}_{2}$ bubbling strongly increases the concentration of $\mathrm{CO}_{2}$ in water. ${ }^{55}$ This is due to a faster solvation of gaseous $\mathrm{CO}_{2}$ compared to the rate of conversion of dissolved $\mathrm{CO}_{2}$ into carbonic acid $\mathrm{H}_{2} \mathrm{CO}_{3}$. Considering that $\mathrm{CO}_{2}$ is the sole substrate that undergoes reduction to formate via hydride transfer at the tungsten active site of MeFoDH1, 56 the concentration of $\mathrm{CO}_{2}$ in water can be seen as a limiting factor, making $\mathrm{CO}_{2}$ bubbling a key parameter to reach high formate productivity. Besides $\mathrm{CO}_{2}$ bubbling, poly(ethylene glycol) diglycidyl ether (PEGDGE, $500 \mathrm{Da}$ ) was selected as a functional additive to promote $\mathrm{CO}_{2}$ dissolution in the reaction medium. The electron-rich ether oxygen atoms in the poly(ethylene glycol) chains are believed to be involved in acid-base reactions with dissolved carbon dioxide, which could increase $\mathrm{CO}_{2}$ concentration in the vicinity of MeFoDH1.57 PEGDGE was also selected in order to stabilize enzymes into cross-linked enzyme aggregates (so-called CLEAs) ${ }^{58}$ via the diglycidyl ether end groups that can react with amine groups of both enzymes and cofactors. Furthermore, PEGylation has been reported as an efficient way to enhance the activity of encapsulated dehydrogenases. ${ }^{26,59}$ The results obtained herein support these assumptions. As shown in Figure 1b, in the absence of PEGDGE, formate could not be detected after 5 min reaction (concentration under the detection limit), while its addition in the reaction medium clearly boosted formate production until a plateau was reached at higher PEGDGE/enzyme ratio. Another key parameter is the enzyme concentration (including PtDH and MeFoDH1). At a constant PEGDGE/enzyme ratio of $0.08 \mu \mathrm{L} / \mu \mathrm{g}$ and a constant $\mathrm{PtDH} / \mathrm{MeFoDH} 1$ molar ratio of 0.23 , the increase in enzyme concentration led to a linear increase in formate production (Figure 1c). Those features suggest that, under the selected experimental conditions $\left(0.1 \mathrm{M} \mathrm{NaHCO}{ }_{3}\right.$ together with $\mathrm{CO}_{2}$ bubbling; see section $\mathrm{S} 4$ in Supporting Information for more details), $\mathrm{CO}_{2}$ availability was not a limiting factor anymore.

Another important parameter when dealing with tandem enzymatic reaction is the relative activity of the enzymes, expressed in unit ratio $\mathrm{U}_{\mathrm{PtOH}} / \mathrm{U}_{\mathrm{MeFO}} \mathrm{DH}_{1}$ (see sections S1-2). The second enzyme should have a higher activity than the first one. As shown in Figure 1d, an increase in $\mathrm{U}_{\mathrm{PtOH}} / \mathrm{U}_{\mathrm{MefOOH} 1}$ ratio up to 5 led to a significant increase in formate production. The highest productivity in batch with the two free enzymes was 0.88 $\mu$ molformate $\mathrm{min}^{-1} \mathrm{mg}^{-1} \mathrm{MeFOOH1}$ over $30 \mathrm{~min}$ and was obtained with a composition, in molar ratio, of 1 MeFoDH1: 5 PtDH: 341 NAD*: 91 PEGDGE. This result corresponds to the production of 6.5 $\mu \mathrm{mol}_{\text {formate }}$ in $2 \mathrm{~mL}$ solution. The turnover number (TON) and the turnover frequency (TOF) for MeFoDH1 were 4460 and $149 \mathrm{~min}$ ${ }^{1}$, respectively (Table 1 ). Productivity, TON and TOF are the highest reported to date for the NAD-dependent biocatalytic production of formate from $\mathrm{CO}_{2}$ gas. ${ }^{29,30,60}$

In order to demonstrate the feasibility of applying this enzyme tandem reaction to a supported continuous flow set- 
up, the whole optimized biocatalytic system - i.e. MeFoDH1, PtDH, NAD* and PEGDGE - was immobilized within particular hierarchical porous inorganic monoliths. Those monoliths are obtained via spinodal decomposition ${ }^{61}$ and contain homogeneous and interconnected flow-through macropores and mesopores with high surface area. In literature, analogous silica-based monoliths were reported for flow-through heterogeneous catalysis ${ }^{62}$ and biocatalysis ${ }^{63}$. Their singular textural properties were demonstrated to significantly improve productivity due to an optimal mass transport leading to perfectly defined contact times. ${ }^{62}$ Herein, a silica monolith ${ }^{62}$ and its carbon replica ${ }^{64}$ were both employed as porous supports for the immobilization of the optimized bi-enzymatic system and their performances were compared in continuous flow processes. Both monoliths display a co-continuous skeleton with large homogeneous macropores of $40 \mu \mathrm{m}$ diameter (Figure 2a and section S5, Figure S9 and Table S1) for an optimize permeability with very low drop pressure. ${ }^{65}$ The silica monolith features large mesopores diameter $(20 \mathrm{~nm})$, leading to a specific surface area of $300 \mathrm{~m}^{2} \mathrm{~g}^{-1}\left(80 \mathrm{~m}^{2} \mathrm{~cm}^{-3}\right)$. Its carbon replica displays a bimodal mesoporosity (diameter of 7 and $14 \mathrm{~nm}$; Figure 2b) and a larger specific surface area of $1000 \mathrm{~m}^{2} \mathrm{~g}^{-1}$ (200 $\mathrm{m}^{2} \mathrm{~cm}^{-3}$ ). Cylinder-shaped monoliths of $0.6 \mathrm{~cm}$ diameter and 1.4 $\mathrm{cm}$ length for the carbon monolith and $1.1 \mathrm{~cm}$ length for the silica monolith (corresponding both to $0.24 \mathrm{~mL}$ of total pore volume) were cladded with impermeable PTFE heat-shrink tubing together with two stainless steel tubes at each end and connected by Swagelok fittings to a peristaltic pump (Figure 2c). The cladded monoliths were then impregnated under flow $(0.2$ $\mathrm{mL} \mathrm{min}^{-1}$ ) with the optimized biocatalytic system (1 MeFoDH1: 5 PtDH: 341 NAD*: 91 PEGDGE) in sodium phosphite buffer (0.5 $\mathrm{M}, \mathrm{pH} 6.4)$ solution $(0.28 \mathrm{~mL})$ in order to fill the total pore volume of the monoliths. The monoliths were then kept at $4{ }^{\circ} \mathrm{C}$ for $\mathbf{2 4}$ hours in static conditions to insure the immobilization inside the mesoporosity via the cross-linking between PEGDGE, enzymes and cofactors. Subsequently, the monoliths were washed with sodium phosphite buffer under flow $(20 \mathrm{~mL}$ at 0.2 $\mathrm{mL} \mathrm{min}^{-1}$ ) to leach out non-cross-linked molecules. The two reactors were named CLEAs@Carbon and CLEAs@Silica.

A sodium phosphite buffer solution containing $\mathrm{NaHCO}_{3}$ in which $\mathrm{CO}_{2}$ was bubbled, was flowed through the monoliths at a flow rate of $0.2 \mathrm{~mL} \mathrm{~min}^{-1}$, corresponding to a contact time of 1 $\mathrm{min}$. Formate production was monitored within time for $40 \mathrm{~min}$ (Figure 3, Figure S10). For CLEAs@Silica monolith, the formate productivity was low (space-time yield (STY) of $0.1 \mathrm{mmol}_{\text {formate }}$ $\mathrm{min}^{-1} \mathrm{~L}^{-1}$ reactor over $40 \mathrm{~min}$ ), whereas for CLEAs@Carbon monolith, the formate productivity was much higher (0.6 mmoltormate $\mathrm{min}^{-1} \mathrm{~L}^{-1}$ reactor over $40 \mathrm{~min}$ ) and reached 0.99 $\mu \mathrm{mol}_{\text {formate }} \mathrm{min}^{-1} \mathrm{mg}^{-1} \mathrm{MeFOOH}$, which was higher than the one obtained in batch with free enzymes $\left(0.88 \mu \mathrm{mol}_{\text {formate }} \mathrm{min}^{-1} \mathrm{mg}^{-1}\right.$ MefoOH1). While in batch with free enzymes, a plateau was reached after 5 min of reaction, the CLEAs@Carbon monolith allowed a continuous production over $\mathbf{4 0}$ minutes, presumably due to the equilibrium displacement of the reaction and to a shorter contact time. Interestingly, carbon reactors were more efficient than silica reactors (Figure 3 ), probably due to the higher $\mathrm{CO}_{2}$ adsorption capacity of carbon monoliths $(2.16 \mathrm{mmol}$ $\left.\mathrm{g}^{-1}, 0.43 \mathrm{mmol} \mathrm{cm}^{-3}\right)$ in comparison to silica monoliths. $(0.47$ $\mathrm{mmol} \mathrm{g}^{-1}, 0.12 \mathrm{mmol} \mathrm{cm}^{-3}$ ) (see section S6,Figure $\mathrm{CO}_{2}$ localization in the vicinity of the enzymes.

However, the production rate of formate decreased at each uptake (from TOF $=222 \mathrm{~min}^{-1}$ after $5 \mathrm{~min}$ to TOF $=101 \mathrm{~min}^{-1}$ at $40 \mathrm{~min}$ ) and formate concentration was below accurate detection after $45 \mathrm{~min}$. With silica reactors, formate concentration was below accurate detection after only $15 \mathrm{~min}$. As the leaching of enzymes and cofactor was not detected, one may assume that the decrease of the activity rate over time might be due to the spontaneous degradation of NADH in mild acidic medium and in the presence of $\mathrm{CO}_{2}$, as reported in literature ${ }^{27}$. NADH degradation occured at $\mathrm{pH}<7.8$ and our reaction was run at a pH of 6.4 to 6.3. Furthermore, the formation of carbonic acid ( $\mathrm{pKa}$ 6.37) by solvation of $\mathrm{CO}_{2}$ could decrease locally the $\mathrm{pH}$ around NADH. Moderate increase in $\mathrm{pH}$ and/or addition of ionic liquid (IL) in the reaction medium ${ }^{27,53}$ to form $\mathrm{CO}_{2} / 1 \mathrm{~L} / \mathrm{H}_{2} \mathrm{O}$ aggregates, which avoid carbonic acid formation, are some investigations we will further follow to stabilize NADH. Moreover, taking into account the price of sodium phosphite and its use in a large excess (yielding a very low conversion rate to phosphate of $c a .0 .225 \%$ for CLEAs@Carbon), a recycling procedure must be considered to better improve the sustainability of our system.

As shown in Table 1, the catalytic activities of CLEAs@Carbon monolith reactors, assessed through TON and TOF values, are very close to the one of free enzymes in batch. This feature demonstrates the effective immobilization of MeFoDH1, PtDH and NAD* within the carbon monolith together with an excellent $\mathrm{CO}_{2}$ availability.

Despite the stability issue of NADH, the TOF determined per mol of MeFoDH (i.e. per mol of tungsten) in CLEAs@Carbon monolith is superior to all NAD-dependent biocatalytic systems. ${ }^{31}$ This value $\left(166 \mathrm{~min}^{-1}\right)$ also surpasses most of the TOF values reported in literature for organometallic-based hydrogenation catalysts, ${ }^{2}$ (bio)electrocatalysts, ${ }^{10,} 11,38$ and photo(electro)catalysts ${ }^{13}$ (see section S7, Table S2 in Supporting Information). Miller et al. ${ }^{37}$ reported higher TOF and TON using a photocatalytic system with a tungsten-dependent FoDH $(D v H-$ FoDH) and without NAD. The latter, however, had to operate under nitrogen atmosphere to protect the enzyme from aerobic damage. Interestingly, the STY reported for CLEAs@Carbon monolith is superior to the one recently reported by Park et al. ${ }^{66}$ for $\mathrm{CO}_{2}$ hydrogenation to formic acid over heterogenized ruthenium catalysts using a fixed bed reactor $\left(0.12 \mathrm{mmol}_{\mathrm{FA}} \mathrm{min}-\right.$ ${ }^{1} \mathrm{~L}^{-1}$ reactor over 30 days at $140^{\circ} \mathrm{C}$ and 140 bars). Nevertheless, the catalytic activity of CLEAs@Carbon monolith per mol of metal (TON and TOF) is inferior to the best ruthenium ${ }^{66-68}$ and iridiumbased ${ }^{3,69}$ catalytic systems (see Table \$2). Those last processes, however, operate under harsh conditions (i.e. $80-140^{\circ} \mathrm{C}$ and 80 140 bars of $\left.\mathrm{CO}_{2} / \mathrm{H}_{2}\right)$, and some new less costly technologies need to be developed. To the best of our knowledge, CLEAs@Carbon monolith represents one of the most efficient processes running under ambient conditions without the need of pressurized $\mathrm{H}_{2}$. Once the long-term stability issue is solved, the development of enzymatic reactors in continuous flow could represent a sustainable alternative to organometallic 
catalysts in batch, enabling a safer, lower energy consuming process with no separation of catalyst, no filtration, no compression of $\mathrm{CO}_{2}$ and above all no pressurized $\mathrm{H}_{2}$. Beyond the production of formate, the biocatalytic reactor developed herein is the first step towards a multienzymatic cascade reaction to produce methanol. ${ }^{26,53}$ Owing to the large market demand for methanol and to the low profitability if produced from $\mathrm{CO}_{2} \mathrm{RR}$ electrochemical systems ${ }^{19}$, enzymatic flow-through reactors to obtain methanol from $\mathrm{CO}_{2}$ might become an economically viable alternative in a near future. The development of such reactors is underway.

\section{Conclusions}

In summary, we have demonstrated the ability of the formate dehydrogenase from $M$. extorquens AM1 (MeFoDH1) and a phosphite dehydrogenase mutant from Ps. stutzeri (PtDH) to work in a tandem reaction, with a clean in situ regeneration of the NADH cofactor. The use of $\mathrm{CO}_{2}$ bubbling, poly(ethylene glycol) diglycidyl ether and an unconventional optimized carbon monolithic support for enzymes immobilization allowed reaching the highest productivity reported to date for NADdependent biocatalytic systems for the production of formate from $\mathrm{CO}_{2}$ gas. A flow-through reactor was developed leading to high STY (0.6 mmolformate $\mathrm{min}^{-1} \mathrm{~L}^{-1}$ reactor) and competitive TON (6 653) and TOF (166 $\mathrm{min}^{-1}$ ) without the need of $H_{2}$ and under ambient conditions. Despite a modest stability, the flowthrough enzymes reactor developed herein is superior to all NAD-dependent biocatalytic systems and is also superior to most of the hydrogenation catalysts, electrocatalysts and photo(electro)catalysts reported in literature. Further investigations on the reaction medium (e.g. higher $\mathrm{pH}$, slight increase in $\mathrm{CO}_{2}$ pressure, addition of $\mathrm{IL}$ ), the immobilization method and/or the use of more stable NAD synthetic analogues ${ }^{70,71}$ are underway.

\section{Conflicts of interest}

There are no conflicts to declare.

\section{Notes and references}

‡ This research was supported by Institut Carnot Chimie Balard and LabEx Agro (408-15AC3) and French ministry for PhD financial support.

$\S$ The authors wish to acknowledge the support from the Chemistry Plateform of Campus in Montpellier (Plateform MEA University Montpellier), on which SEM pictures have been performed.

P. Z. V. Masson-Delmotte, H.-O. Pörtner, D. Roberts, J. Skea, P.R. Shukla, A. Pirani, W. Moufouma-Okia, C. Péan, R. Pidcock, S. Connors, J.B.R. Matthews, Y. Chen, X. Zhou, M.I. Gomis, E. Lonnoy, T. Maycock, M. Tignor, and T. Waterfield, IPCC, 2018: Summary for Policymakers. In: Global Warming of $1.5^{\circ} \mathrm{C}$.
A. Alvarez, A. Bansode, A. Urakawa, A. V. Baykkina, T-A Wezendonk, M. Makkee, J. Gascon and F1 Kapteljn, Chemk Rev, 2017, 117, 9804-9838.

3. X. Z. Shao, X. F. Yang, J. M. Xu, S. Liu, S. Miao, X. Y. Liu, X. Su, H. M. Duan, Y. Q. Huang and T. Zhang, Chem-Us, 2019, 5, 693-705.

4. S. Masuda, K. Mori, Y. Futamura and H. Yamashita, Acs Catal, 2018, 8, 2277-2285.

5. J. Eppinger and K. W. Huang, Acs Energy Lett, 2017, 2, 188-195.

6. EPFL, Team creates the world's first formic acid-based fuel cell, https://phys.org/news/2018-03-team-world-formicacid-based-fuel.html, (accessed October 9, 2019).

7. MarketWatch, Formic Acid Market 2020 Industry Demand, Share, Global Trend, Business Growth, Top Key Players, Business Statistics and Research Methodology by Forecast to 2024, https://www.marketwatch.com/pressrelease/formic-acid-market-2020-industry-demand-shareglobal-trend-business-growth-top-key-players-businessstatistics-and-research-methodology-by-forecast-to-20242020-04-02, (accessed April 24, 2020).

8. S. Roy, B. Sharma, J. Peaut, P. Simon, M. Fontecave, P. D. Tran, E. Derat and V. Artero, J Am Chem Soc, 2017, 139, 3685-3696.

9. F. Proietto, B. Schiavo, A. Galia and O. Scialdone, Electrochim Acta, 2018, 277, 30-40.

10. W. Lee, Y. E. Kim, M. H. Youn, S. K. Jeong and K. T. Park, Angew Chem Int Edit, 2018, 57, 6883-6887.

11. C. Xia, P. Zhu, Q. Jiang, Y. Pan, W. T. Liang, E. Stavitsk, H. N. Alshareef and H. T. Wang, Nat Energy, 2019, 4, 776 785.

12. G. Diaz-Sainz, M. Alvarez-Guerra, J. Solla-Gullon, L. GarciaCruz, V. Montiel and A. Irabien, J Co2 Util, 2019, 34, 12-19.

13. B. W. Zhou, X. H. Kong, S. Vanka, S. B. Cheng, N. Pant, S. Chu, P. Ghamari, Y. C. Wang, G. Botton, H. Cuo and Z. T. Mi, Energ Environ Sci, 2019, 12, 2842-2848.

14. S. Bernadet, E. Tavernier, D. M. Ta, R. A. L. Vallee, S. Ravaine, A. Fecant and R. Backov, Adv Funct Mater, 2019, 29.

15. F. Sastre, A. V. Puga, L. C. Liu, A. Corma and H. Garcia, J Am Chem Soc, 2014, 136, 6798-6801.

16. B. W. Zhou, J. L. Song, C. Xie, C. J. Chen, Q. L. Qian and B. X. Han, Acs Sustain Chem Eng, 2018, 6, 5754-+.

17. S. Verma, B. Kim, H. Jhong, S. C. Ma and P. J. A. Kenis, Chemsuschem, 2016, 9, 1972-1979.

18. O. S. Bushuyev, P. De Luna, C. T. Dinh, L. Tao, G. Saur, J. van de Lagemaat, S. O. Kelley and E. H. Sargent, Joule, 2018, 2, 825-832.

19. M. Jouny, W. Luc and F. Jiao, Ind Eng Chem Res, 2018, 57, 2165-2177.

20. R. A. Sheldon and J. M. Woodley, Chem Rev, 2018, 118, 801-838.

21. L. Jiao, H. Y. Yan, Y. Wu, W. L. Gu, C. Z. Zhu, D. Du and Y. H. Lin, Angew Chem Int Edit, 2020, 59, 2565-2576.

22. J. F. Shi, Y. J. Jiang, Z. Y. Jiang, X. Y. Wang, X. L. Wang, S. H. Zhang, P. P. Han and C. Yang, Chem Soc Rev, 2015, 44, 5981-6000.

23. A. Alissandratos and C. J. Easton, Beilstein J Org Chem, $2015,11,2370-2387$.

24. K. Schuchmann and V. Muller, Science, 2013, 342, 13821385. 

2015, 20, 287-309.

26. R. Cazelles, J. Drone, F. Fajula, O. Ersen, S. Moldovan and A. Galarneau, New J Chem, 2013, 37, 3721-3730.

27. Z. B. Zhang, J. Muschiol, Y. H. Huang, S. B. Sigurdardottir, N. von Solms, A. E. Daugaard, J. Wei, J. Q. Luo, B. H. Xu, S. J. Zhang and M. Pinelo, Green Chem, 2018, 20, 4339-4348. S. Kim, M. K. Kim, S. H. Lee, S. Yoon and K. D. Jung, $J$ Mol Catal B-Enzym, 2014, 102, 9-15.

29. Y. K. Kim, S. Y. Lee and B. K. Oh, Rsc Adv, 2016, 6, 109978 109982.

30. S. Ikeyama and Y. Amao, Chemcatchem, 2017, 9, 833-838.

31. Y. Chen, P. Li, J. Zhou, C. T. Buru, L. Đordević, P. Li, X. Zhang, M. M. Cetin, J. F. Stoddart, S. I. Stupp, M. R.

Wasielewski and O. K. Farha, J. Am. Chem. Soc., 2020, 142.

32. H. Choe, J. M. Ha, J. C. Joo, H. Kim, H. J. Yoon, S. Kim, S. H. Son, R. M. Gengan, S. T. Jeon, R. Chang, K. D. Jung, Y. H. Kim and H. H. Lee, Acta Crystallogr D, 2015, 71, 313-323.

33. H. Choe, J. C. Joo, D. H. Cho, M. H. Kim, S. H. Lee, K. D. Jung and Y. H. Kim, Plos One, 2014, 9.

34. D. H. Nam, S. K. Kuk, H. Choe, S. Lee, J. W. Ko, E. J. Son, E. G. Choi, Y. H. Kim and C. B. Park, Green Chem, 2016, 18, 5989-5993.

35. T. Hartmann and S. Leimkuhler, Febs J, 2013, 280, $6083-$ 6096.

36. A. Alissandratos, H. K. Kim, H. Matthews, J. E. Hennessy, A. Philbrook and C. J. Easton, Appl Environ Microb, 2013, 79, 741-744.

37. M. Miller, W. E. Robinson, A. R. Oliveira, N. Heidary, N. Kornienko, J. Warnan, I. A. C. Pereira and E. Reisner, Angew Chem Int Edit, 2019, 58, 4601-4605.

38. J. Szczesny, A. Ruff, A. R. Oliveira, M. Pita, I. A. C. Pereira, A. L. De Lacey and W. Schuhmann, Acs Energy Lett, 2020, 5, 321-327.

39. M. Laukel, L. Chistoserdova, M. E. Lidstrom and J. A. Vorholt, Eur J Biochem, 2003, 270, 325-333.

40. K. Sakai, Y. Sugimoto, Y. Kitazumi, O. Shirai, K. Takagi and K. Kano, Electrochim Acta, 2017, 228, 537-544.

41. K. Sakai, Y. Kitazumi, O. Shirai, K. Takagi and K. Kano, Electrochem Commun, 2016, 73, 85-88.

42. K. Sakai, Y. Kitazumi, O. Shirai and K. Kano, Electrochem Commun, 2016, 65, 31-34.

43. K. Sakai, Y. Kitazumi, O. Shirai, K. Takagi and K. Kano, Acs Catal, 2017, 7, 5668-5673.

44. X. D. Wang, T. Saba, H. H. P. Yiu, R. F. Howe, J. A. Anderson and J. F. Shi, Chem-Us, 2017, 2, 621-654.

45. X. D. Wang and H. H. P. Yiu, Acs Cotal, 2016, 6, 1880-1886.

46. L. Zhang, N. Vila, G. W. Kohring, A. Walcarius and M. Etienne, Acs Catal, 2017, 7, 4386-4394.

47. B. X. Tan, D. P. Hickey, R. D. Milton, F. Giroud and S. D. Minteer, J Electrochem Soc, 2015, 162, H102-H107.

48. R. K. Yadav, J. O. Baeg, G. H. Oh, N. J. Park, K. J. Kong, J. Kim, D. W. Hwang and S. K. Biswas, J Am Chem Soc, 2012, 134, 11455-11461.

49. R. K. Yadav, G. H. Oh, N. J. Park, A. Kumar, K. J. Kong and J. O. Baeg, J Am Chem Soc, 2014, 136, 16728-16731.

50. J. Liu, R. Cazelles, Z. P. Chen, H. Zhou, A. Galarneau and M. Antonietti, Phys Chem Chem Phys, 2014, 16, 14699-14705.

51. H. A. Relyea and W. A. van der Donk, Bioorg Chem, 2005, 33, 171-189.

52. J. M. Vrtis, A. K. White, W. W. Metcalf and W. A. van der Donk, Angew Chem Int Edit, 2002, 41, 3257-+.
53. R. K. Singh, R. Singh, D. Sivakumar, S. Kondaveeti, T.Kirmetha J. L. Li, B. H. Sung, B. K. Cho, D. R. Kim; So Corampdico $0952 \mathrm{~K}$ Kalia, Y. H. P. J. Zhang, H. M. Zhao, Y. C. Kang and J. K. Lee, Acs Cotal, 2018, 8, 11085-11093.

54. T. W. Johannes, R. D. Woodyer and H. M. Zhao, Appl Environ Microb, 2005, 71, 5728-5734.

55. H. Zhong, K. Fujii, Y. Nakano and F. M. Jin, J Phys Chem C, 2015, 119, 55-61.

56. L. B. Maia, L. Fonseca, I. Moura and J. J. G. Moura, J Am Chem Soc, 2016, 138, 8834-8846.

57. O. Aschenbrenner and P. Styring, Energ Environ Sci, 2010, 3, 1106-1113.

58. R. A. Sheldon and S. van Pelt, Chem Soc Rev, 2013, 42, 6223-6235.

59. W. Hong, S. F. Huang and Z. Y. Jiang, Catal Today, 2004, 98, 545-552.

60. L. J. Zhang, J. Y. Liu, J. Ong and S. F. Y. Li, Chemosphere, 2016, 162, 228-234.

61. K. Nakanishi, J Porous Mat, 1997, 4, 67-112.

62. A. Galarneau, A. Sachse, B. Said, C. H. Pelisson, P. Boscaro, N. Brun, L Courtheoux, N. Olivi-Tran, B. Coasne and F. Fajula, Cr Chim, 2016, 19, 231-247.

63. K. Szymanska, M. Pietrowska, J. Kocurek, K. Maresz, A. Koreniuk, J. Mrowiec-Bialon, P. Widlak, E. Magner and A. Jarzebski, Chem Eng J, 2016, 287, 148-154.

64. L. Yu, N. Brun, K. Sakaushi, J. Eckert and M. Titirici, Carbon, 2013, 61, 245-253.

65. A. Galarneau, Z. Abid, B. Said, Y. Didi, K. Szymanska, A. Jarzębski, F. Tancret, H. Hamaizi, A. Bengueddach, F. Di Renzo and F. Fajula, Inorganics, 2016, 4.

66. K. Park, G. H. Gunasekar, S. H. Kim, H. Park, S. Kim, K. Park, K. D. Jung and S. Yoon, Green Chem, 2020, 22, 16391649.

67. A. Weilhard, M. I. Qadir, V. Sans and J. Dupont, Acs Catal, 2018, 8, 1628-t.

68. G. H. Gunasekar, K. D. Jung and S. Yoon, Inorg Chem, 2019, 58, 3717-3723.

69. R. Tanaka, M. Yamashita and K. Nozaki, J Am Chem Soc, 2009, 131, 14168-+.

70. Y. X. Liu, Y. B. Feng, L. Wang, X. J. Guo, W. J. Liu, Q. Li, X. Y. Wang, S. Xue and Z. B. K. Zhao, Acs Catal, 2019, 9, 18831887.

71. C. Nowak, A. Pick, P. Lommes and V. Sieber, Acs Catal, 2017, 7, 5202-5208. 

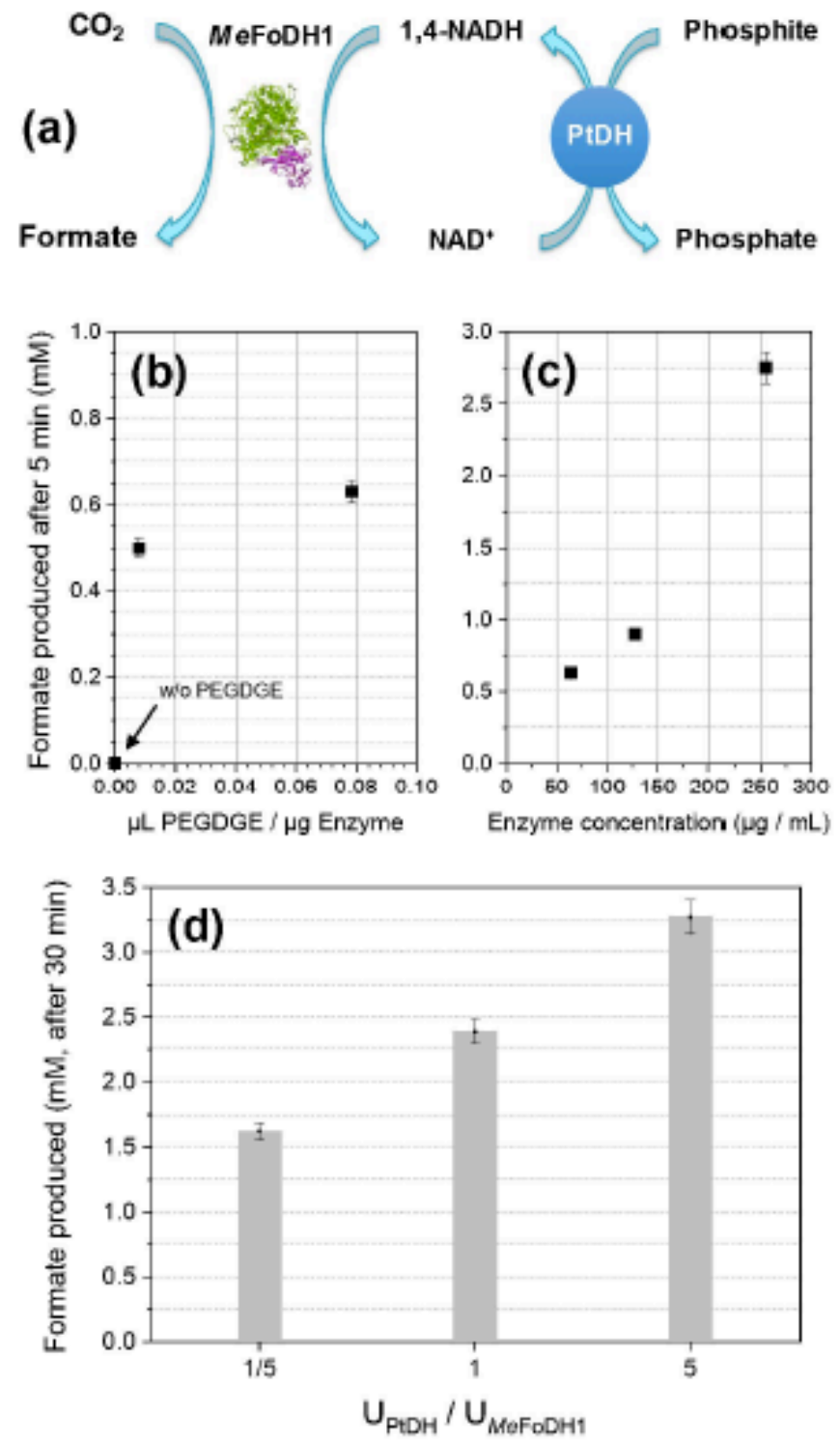

Figure 1. Tandem batch reactor. (a) Schematic representation of the enzyme tandem reaction developed for the production of formate from $\mathrm{CO}_{2}$ gas. (b) Influence of the PEGDGE/Enzyme ratio $(\mu \mathrm{L} / \mu \mathrm{g})$ over formate production after 5 min reaction. (c) Influence of the enzyme concentration $(\mu \mathrm{g} / \mathrm{mL})$ over formate production after $5 \mathrm{~min}$ reaction. (d) Influence of the $\mathrm{U}_{\mathrm{PrDW}} / \mathrm{U}_{\mathrm{MeF} F \mathrm{OH}}$ ratio over formate production after 30 min reaction. 

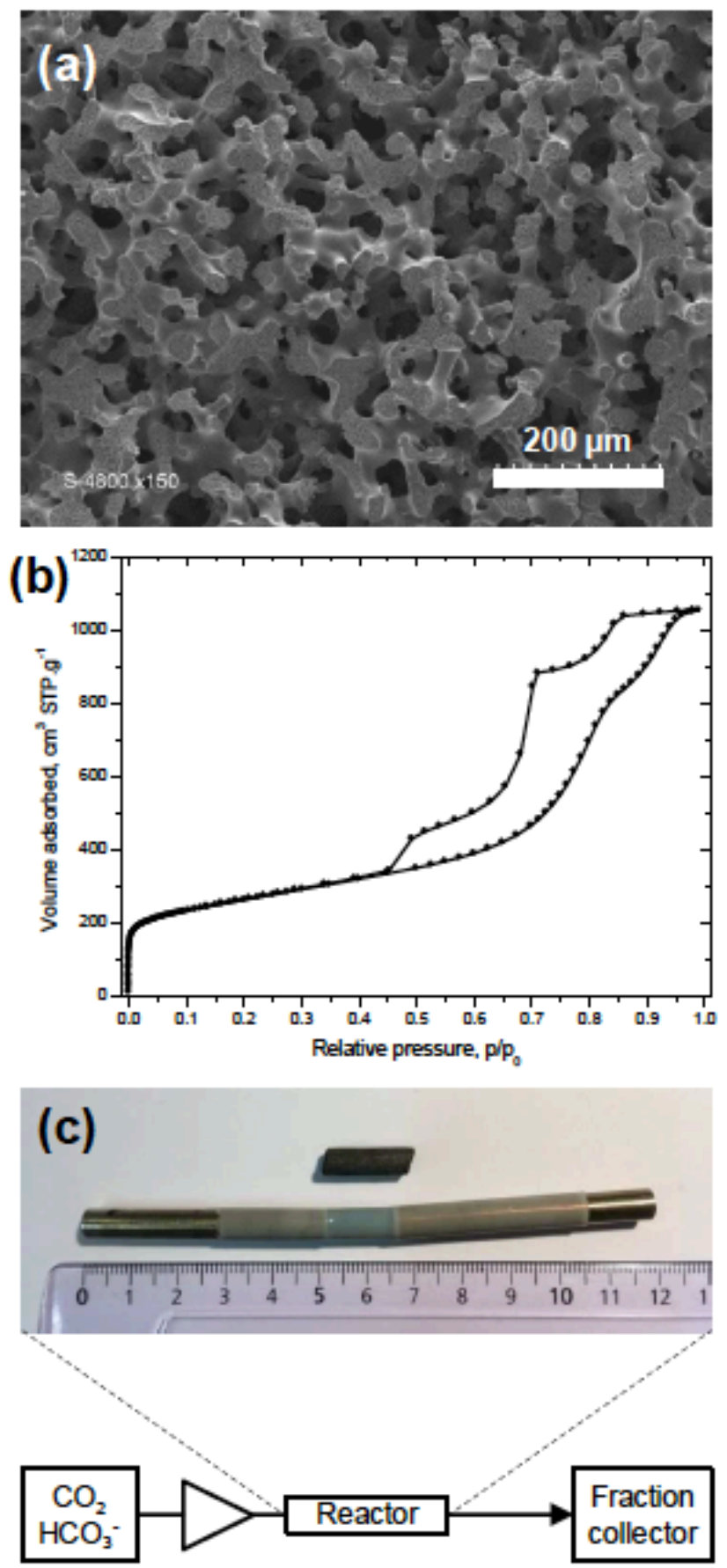

Pump

Figure 2. Flow through reactor. (a) Scanning electron micrograph and (b) Nitrogen sorption isotherm at $77 \mathrm{~K}$ of the carbon monolithic support. (c) Photograph of the carbon monolith (up) and the cladded reactor (bottom). 


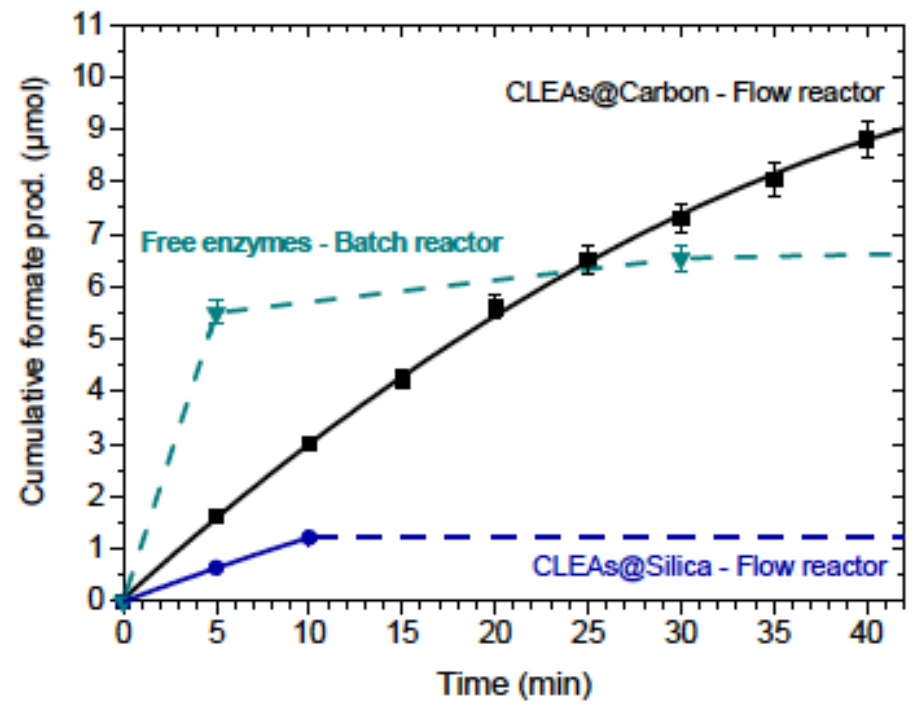

Figure 3. Flow through formate production. Cumulative formate production $(\mu \mathrm{mol})$ over time in a buffered solution saturated in $\mathrm{CO}_{2}$ (0.1 M NaHCO together with $\mathrm{CO}_{2}$ bubbling). Fractions of $1 \mathrm{~mL}$ were collected every 5 minutes. Flow rate: $0.2 \mathrm{mLmin}^{-1}$. Contact time: c.a. $1 \mathrm{~min}$ (Total pore volume within the monolith of ca. $0.24 \mathrm{~mL}$ ). The contact time in the batch reactor corresponds to the reaction time.

Table 1. Catalytic activity of batch (i.e. free enzymes) and flow through (i.e. immobilized CLEAs) reactors.

\begin{tabular}{|c|c|c|c|}
\hline & \\
\hline & & TON & TOFb $^{\prime}\left(\min ^{-1}\right)$ \\
\hline Batch reactor ${ }^{\mathrm{c}}$ & $\mathrm{NAD}^{+}$ & 14 & 0.47 \\
\hline \multirow[t]{2}{*}{ Free enzymes } & PtDH & 890 & 30 \\
\hline & MeFoDH1 & 4460 & 149 \\
\hline Flow through reactor ${ }^{d}$ & $\mathrm{NAD}^{+}$ & 21 & 0.52 \\
\hline \multirow[t]{2}{*}{ CLEAs@carbon } & PtDH & 1328 & 33 \\
\hline & MeFoDH1 & 6653 & 166 \\
\hline
\end{tabular}

'Turnover number (TON) is determined as the number of moles of formate produced per mole of catalyst (i.e. NAD', PtDH or MefoDH) before inactivation. 'burnover frequency (TOF) refers to the TON per minute. 90 minutes reaction. ${ }^{4} 40$ minutes reaction. Based on experimental errors, a standard deviation of $c a .5 \%$ was estimated.

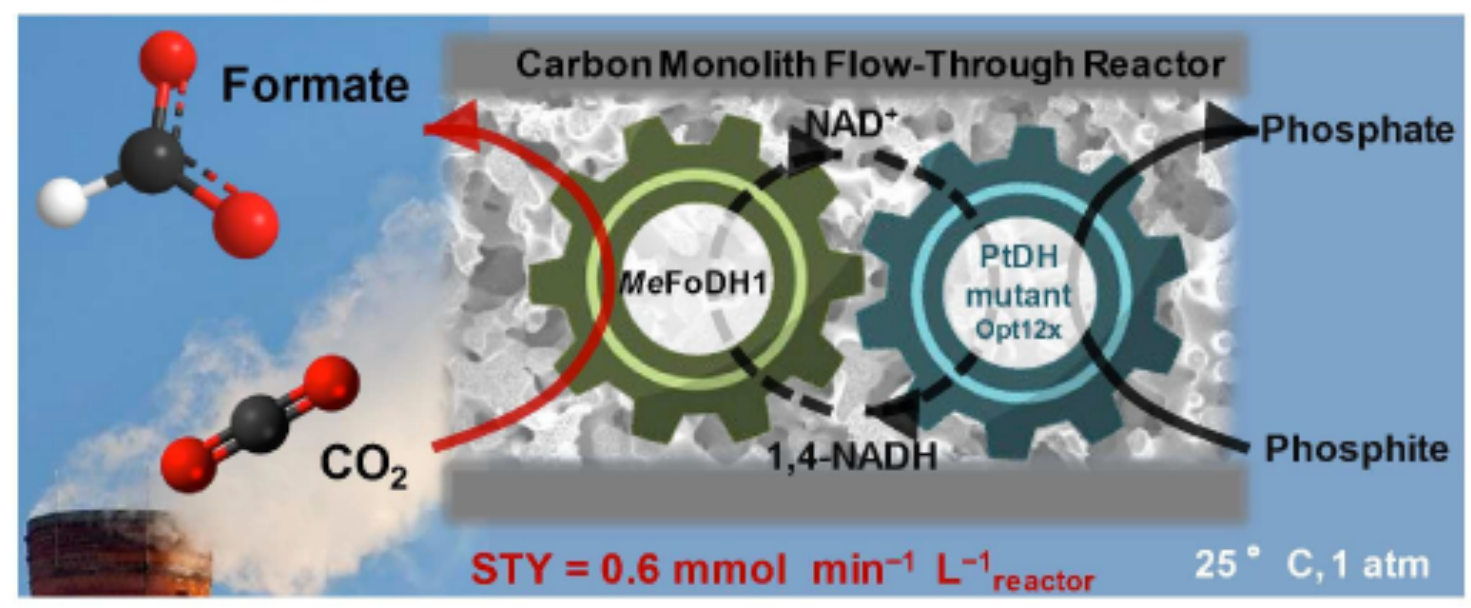

